\title{
Cyto-Histopathological Findings of Myofibroblastoma of the Breast: A Case Report
}

\author{
Meme Myofibroblastomunun Sito-Histopatolojik Bulguları: Olgu Sunumu
}

\author{
(D) Büşra Yaprak Bayrak¹, (D) Ahmet Tuğrul Eruyar1, (D) Abdullah Güneș² \\ ${ }^{1}$ Kocaeli University Faculty of Medicine, Department of Pathology, Kocaeli, Turkey \\ 2University of Health Seciences, Derince Training and Research Hospital, Department of General Surgery, Kocaeli, Turkey
}

\begin{abstract}
Myofibroblastoma of the breast is a rare mesenchymal tumor, probably originating from stromal fibroblasts. In this case report, cyto-histopathological findings of myofibroblastoma of the breast are discussed.

A 68-years-old male patient was admitted to our clinic with a rapidly growing, painless mass in the breast. Radiological examination revealed a mobile, solid mass resembling to fibroadenoma. Fine needle aspiration revealed spindle cell clusters with fibrous stroma and a clear background. Hypocellular aspirates demonstrated neoplastic cells with cyanophilic cytoplasm and mild/moderate pleomorphism, and naked elongated nuclei including fine granular chromatin, nuclear groove and inclusion. The lesion was reported as "benign spindle cell neoplasm". Tru-cut biopsy revealed short fascicules composed of uniform benign spindle cells with hyalinized collagen bands accompanied by mast cells and patchy lymphoid infiltration. Immunoreactivity was positive with CD34, smooth muscle actin (SMA), desmin and vimentin, but negative with CD117, CD10, Epithelial Membrane Antigen, S-100, pan-cytokeratin and p53. This case was reported as "classic variant of myofibroblastoma", and the patient was operated in another clinic. There was no recurrence during follow-up.
\end{abstract}

Myofibroblastoma is a rare, benign mesenchymal tumor, usually seen in the breast parenchyma. While the tumor is diagnosed based on the fibro-myofibroblastic differentiation characteristics, other tumors and tumor-like spindle cell lesions should also be kept in mind. The cytological features of 22 cases in the literature were similar. Aspirates are generally hypercellular with mild-moderate pleopmorphism, nuclear groove and inclusions. Histopathology shows positivity for CD34, vimentin, desmin and SMA. Clinical/radiological characteristics and atypia, growth pattern, mitosis and immunohistochemistry should all be evaluated together. Cytomorphology may be the first step in diagnosis; however, immunohistochemical studies should not be ignored in differential diagnosis.

Keywords: Fine needle aspiration cytology, breast, histopathology, myofibroblastoma

\section{ÖZ}

Memenin myofibroblastomu sık rastlanmayan, olasılıkla stromal fibroblastlardan kaynaklanan mezenkimal bir tümördür. Bu olguda myofibroblastomun sito-histopatolojik bulguları tartıșılmaktadır.

Altmış sekiz yaşında erkek hasta memede hızla büyüyen ağrısız kitle nedeniyle kliniğimize bașvurdu. Muayenede tespit edilen mobil, sert kitlenin radyolojik olarak fibroadenoma'ya benzediği düşünüldü. İnce iğne aspirasyonunda temiz arka planlı, fibröz stromalı ığsi hücre kümeleri görüldü. Hiposellüler aspiratlarda hafif-orta pleomorfizm gösteren, siyanofilik sitoplazmalı, çıplak elonge nükleuslu, nükleer çentik, inklüzyon içeren, ince granüler kromatinli neoplastik hücreler dikkati çekti. Lezyon "benign iğsi hücreli neoplazm" olarak raporlandı. Tru-cut biyopside hyalinize kollajen bantlar arasında uniform, benign iğsi hücrelerden oluşan, mast hücreleri ve yama tarzı lenfoid infiltrasyonun eșlik ettiği kısa fasiküller izlendi. CD34, smooth muscle aktin (SMA), desmin, vimentin ile pozitif, CD117, CD10, epitelyal membran antijen, S-100, pansitokeratin, p53 ile negatif reaksiyon gösterdi. Bu bulgularla "myofibroblastom" olarak raporlandı. Hastanın isteğiyle dış merkezde eksizyon yapıldı. Takiplerinde rekürrens izlenmedi.

Myofibrolastom genelde meme parankiminde görülen, nadir, benign mezenkimal tümördür. Tümörün fibro-myofibroblastik differansiasyon özelliğine bağlı olarak tanı konulurken, diğer tümör ve benzeri iğsi hücreli lezyonlar akılda bulundurmalıdır. Literatürdeki 22 olgunun sitolojik özellikleri benzerdir. Aspiratlarda nükleer çentik/inklüzyonlar bulundurabilen hafiforta pleomorfik iğsi hücreler görülür. Histopatolojisinde CD34, vimentin, desmin ve SMA pozitiftir. Klinik/radyolojik özellikler ve atipi, büyüme paterni, mitoz, immünohistokimyanın hepsi beraber değerlendirilmelidir. Tanıda ilk aşama sitomorfoloji olabilir ancak immünohistokimyasal çalışmalar ayrımsal tanıda göz ardı edilmemelidir.

Anahtar Kelimeler: İnce iğne aspirasyon sitolojisi, meme, histopatoloji, myofibroblastoma
Address for Correspondence/Yazıșma Adresi: Büșra Yaprak Bayrak, Kocaeli University Faculty of Medicine, Department of Pathology, Kocaeli, Turkey

Phone: +90262 3038455 E-mail: busra.yaprakbayrak@kocaeli.edu.tr ORCID ID: orcid.org/0000-0002-0537-3127

Cite this article as/Atıf: Bayrak BY, Eruyar AT, Güneș A. Cyto-Histopathological Findings of Myofibroblastoma of the Breast: A Case Report. İstanbul Med J 2019; 20(2): 148-51.

(c) Copyright 2019 by the Istanbul Training and Research Hospital/Istanbul Medical Journal published by Galenos Publishing House.

(C) Telif Hakkı 2019 İstanbul Ĕgitim ve Araștırma Hastanesi/Istanbul Tıp Dergisi, Galenos Yayınevi tarafından basılmıștır.
Received/Geliș Tarihi: 24.10.2017 Accepted/Kabul Tarihi: 08.06.2018 


\section{Introduction}

Myofibroblastoma of the breast is a rare mesenchymal tumor, probably originating from stromal fibroblasts. Although it is actually defined in males, it can affect both sexes $(1,2)$. In recent years, the morphological spectrum of myofibroblastoma of the breast has widened considerably and has been seen in different unusual variants such as epithelioid, cellular, fibrous, deciduoid-like, lipomatous, myxoid and infiltrating $(2,3)$. Myofibroblastoma has similar morphological, immunohistochemical and cytogenetic findings with spindle cell lipoma and cellular angiofibroma (4). Although there are rare cytological definitions of many isolated patients, the role of cytopathology and histopathology in the preoperative diagnosis of myofibroblastoma has not been established yet (3).

In this case report, we aimed to reveal the cyto-histopathological findings of myofibroblastoma of the breast in a 68-year-old male patient and to discuss special cytological definitions with immunohistochemical criteria in preoperative differential diagnosis.

\section{Case Report}

A 68-year-old male patient with multinodular goiter was admitted to our clinic for a rapidly growing, painless mass in the last month. Physical examination showed a mobile, hard mass in the right breast parenchyma.
There were no nipple and skin changes, and axillary lymph nodes Ultrasonography revealed a $4 \times 5 \mathrm{~cm}$, well-circumscribed, hypoechoic solid nodule located in the retro-areolar area of the right breast, radiologically resembling a fibroadenoma. Fine needle aspiration (FNA) was performed by a radiologist. Alcohol-fixed smears were prepared and rapidly stained with Papanicolaou stain. Breast specimen obtained by was examined by a pathologist. Cytopathological smears showed loosely structured fibrous stromal spindle cell clusters with a clean background without necrosis or inflammation (Figure 1a). Hypocellular aspirates demonstrated neoplastic cells with cyanophilic cytoplasm and mild/ moderate pleomorphism, and naked elongated nuclei including fine granular chromatin, nuclear groove and inclusion (Figure $1 \mathrm{~b}$ and $1 \mathrm{c}$ ). No mitosis was observed. In light of these findings, the lesion was reported as "benign spindle cell neoplasm" and Tru-cut biopsy or excision was recommended for histopathological evaluation. Ultrasonography-guided Tru-cut biopsy was performed and short fascicules composed of uniform benign spindle cells with hyalinized collagen bands accompanied by mast cells and patchy lymphoid infiltration were observed (Figure 2). Tumor cells showed positive reaction with CD34 (Figure 3), smooth muscle actin (SMA) (Figure 4), desmin (Figure 5), vimentin (Figure 6), and negative reaction with CD117 (Figure 7), CD10, epithelial membrane antigen EMA, S-100, pan-cytokeratin (Figure 8) and p53.
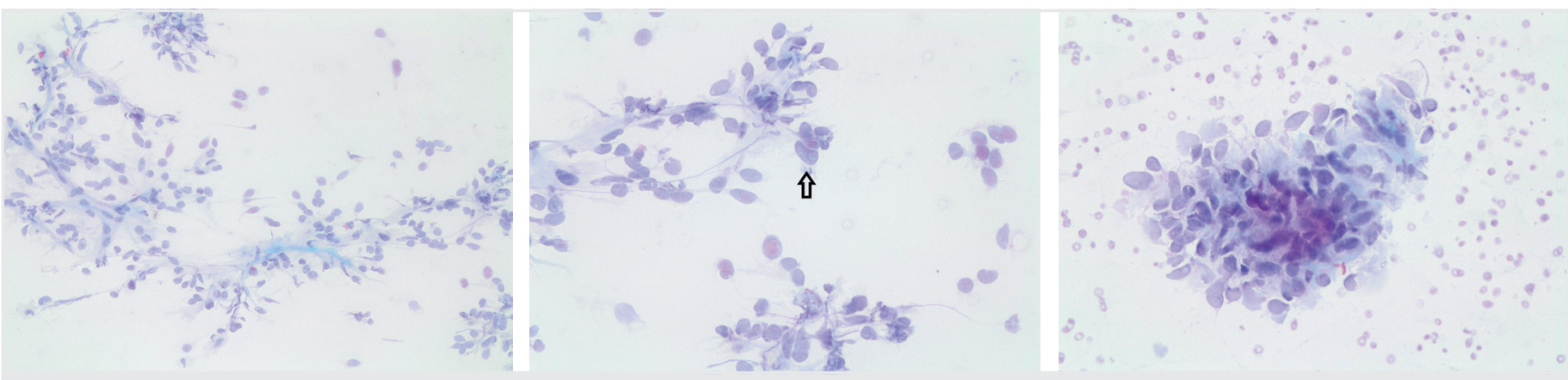

Figure 1. Cytopathological smears of breast sample (Papanicolaou, a: x200, b and c: x400)

1a. Spindle cells with narrow eosinophilic cytoplasm intermingled with extracellular matrix material

1b. Individually dispersed spindle cells with pseudo-inclusion and oval nuclei

1c. Cohesive cell cluster with fine granular chromatin and without nuclear pleomorphism

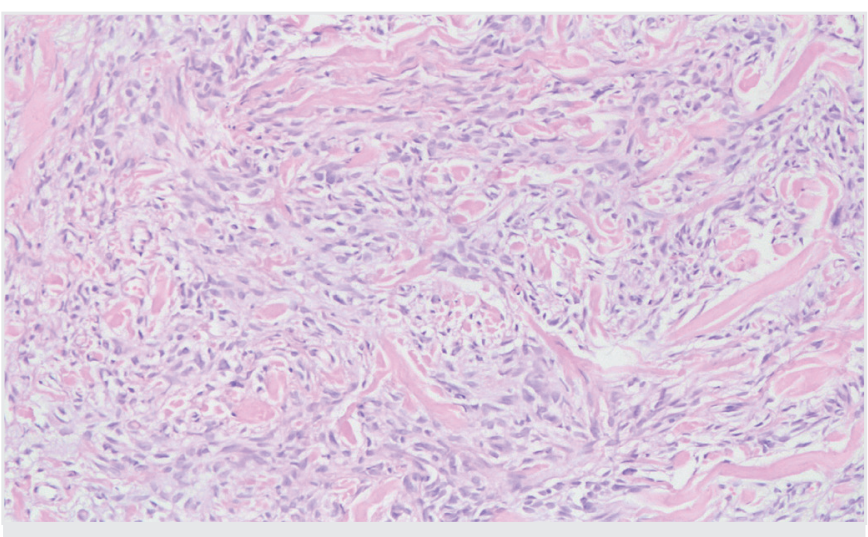

Figure 2. Histopathological appearance of myofibroblastoma (hematoxylin\&eosin, x200). Uniform, large spindle cells without mitotic activity and necrosis that were arranged in fascicles and separated by hyalinized collagen bands without ducts or lobules

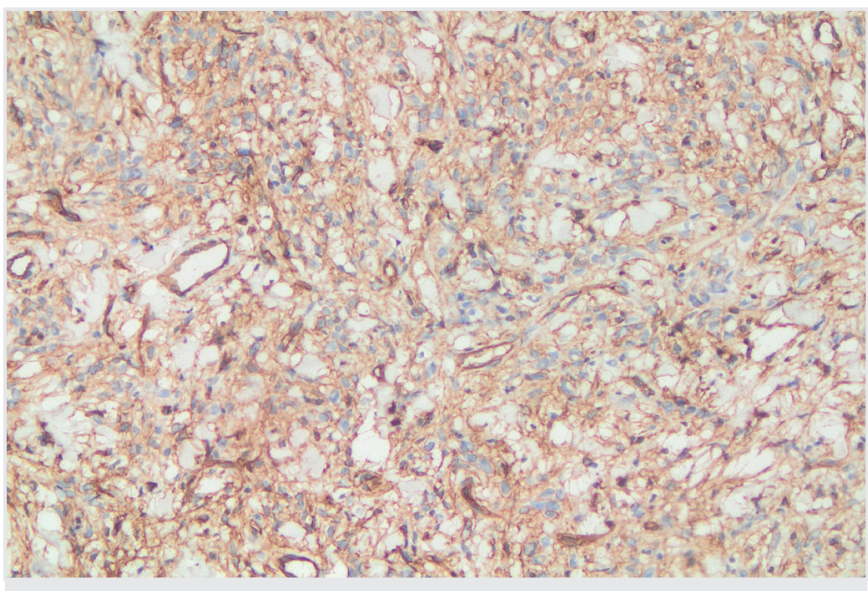

Figure 3. Positive immunohistochemical profile of myofibroblastoma case for CD34 (x200) 


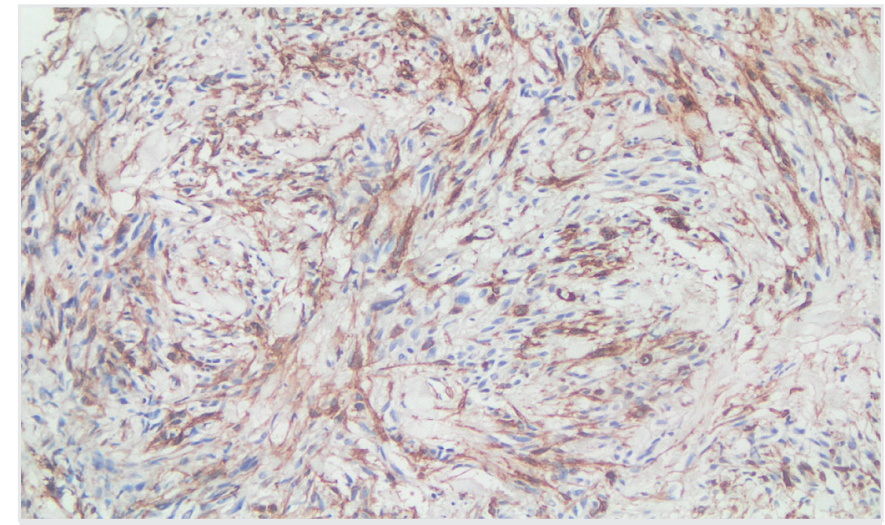

Figure 4. Positive immunohistochemical profile of myofibroblastoma case for Smooth Muscle Actin (x200)

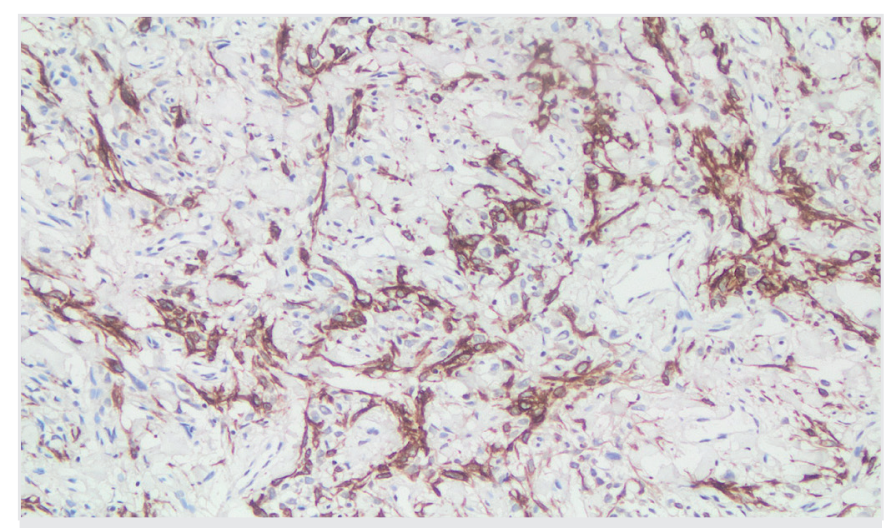

Figure 5. Positive immunohistochemical profile of myofibroblastoma case for desmin $(x 200)$

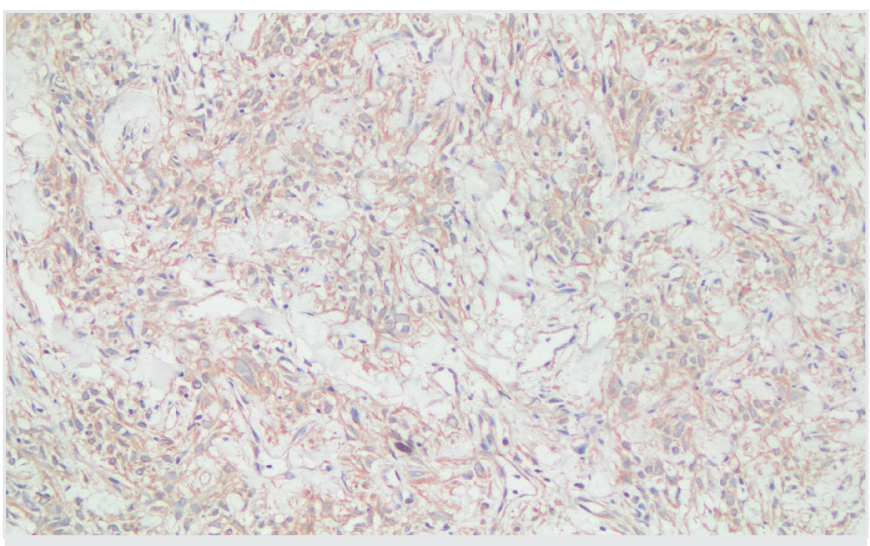

Figure 6. Positive immunohistochemical profile of myofibroblastoma case for vimentin (x200)

All antibodies used in the immunohistochemistry device (Leica bondmix; Leica Biosystems, Newcastle, United Kingdom) were obtained from Leica Biosystems (Newcastle, United Kingdom). Accompanied by morphological and immunohistochemical findings, this breast tumor was reported as "myofibroblastoma, classical variant". The mass excision was performed at an external center upon request of the patient. No recurrence was observed in the patient for three months.

Verbal and written informed consent was obtained from the patient who participated in this study.

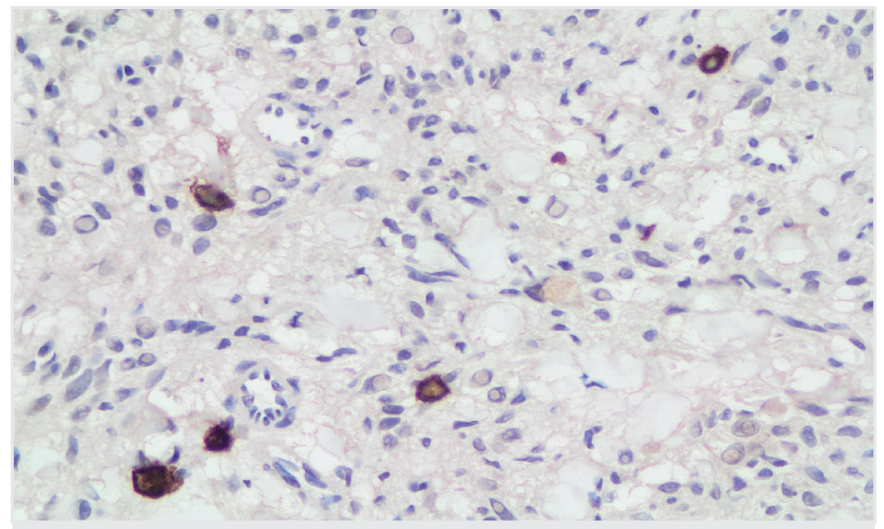

Figure 7. Negative immunohistochemical profile of myofibroblastoma case for CD117 (x200)

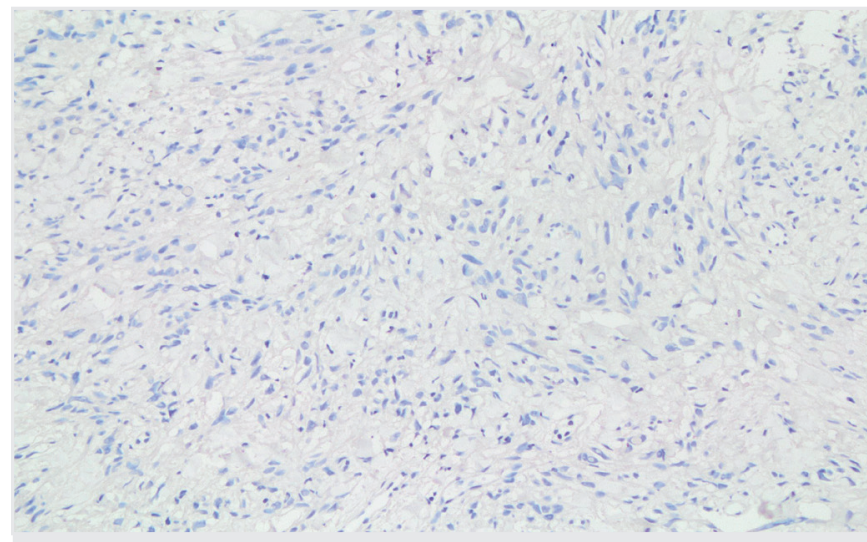

Figure 8. Negative immunohistochemical profile of myofibroblastoma case for pan-cytokeratin (x200)

\section{Discussion}

Myofibroblastoma is a rare, typically slow-growing, well-circumscribed, mobile, benign mesenchymal spindle cell tumor, which is usually seen in breast parenchyma, and therefore may be confused with fibroadenoma in physical examination and mammography. Clinicopathological discrimination was first made by Wargotz et al. (5). It is most commonly seen in postmenopausal women and elderly men. Seventy cases have been reported in the literature since 2008 (6). However, since wide morphologic and immunohistochemical spectrum due to the fibromyofibroblastic differentiation of this unusual prototypic tumor pathologists should be aware of the differential diagnosis.

When any spindle cell lesion was detected cytologically or histopathologically in the breast, spindle cell metaplastic carcinoma, malignant phyllodes tumor as well as fibromatosis, spindle cell lipoma, which may contain similar genetic abnormalities and histological features, scar, postoperative spindle cell nodule, myofibroblastoma, pseudoangiomatous stromal hyperplasia (fascicular type), leiomyoma, adenomyoepithelioma, nodular fasciitis, solitary fibrous tumor inflammatory myofibroblastic tumor, peripheral nerve sheath tumor smooth muscle tumors, primary sarcoma, metastatic sarcoma, metastatic spindle cell carcinoma and metastatic malignant melanoma should be kept in mind in the differential diagnosis (7). 
Spindle cell carcinoma in a spindle cell cluster containing a small number of epithelial components (glandular, squamous) with chondroid, osseous heterologous elements and obvious ductal carcinoma in situ may be confused with long and broad fascicular fibromatosis, which is clinically and radiologically mixed with carcinoma, consisting of benign spindle cells that extend into the surrounding fat and glandular parenchyma and invade breast ducts and lobules, and express nuclear $\beta$-catenin. Nodular fasciitis is a hypercellular, "spindle cell tissue culture" like, fast growing, well-circumscribed, superficial mass consisting of short fascicles and whorls with high mitotic index, stromal myxoid appearance, extravasated erythrocyte, lymphoid clusters and cells with variable collagen accumulation. Postoperative spindle cell nodule is a benign mesenchymal lesion composed of myofibroblastic spindle cells with mild/medium nuclear pleomorphism, small vessel proliferation, hemosiderin-laden macrophages, foamy cells and lymphocytes. There is no surgical history in inflammatory myofibroblastic tumor and marked inflammatory infiltration is observed (7).

Various patterns can be observed histologically (2). The classic type is seen as a well-limited tumor with no real capsule and it has various variants. They can be referred as cellular variant (cell stroma ratio is higher than classic), collagenous variant (containing marked stromal collagen in less cellularity), infiltrative variant (tumor infiltrating normal breast duct, lobules and fat tissue, and having irregular margin), myxoid variant (with myxoid stroma), lipomatous variant (with primary fat tissue component), decidual variant (solid/trabecular nests of cells with large wide cytoplasm), and epithelioid variant (consisting of cells with epithelioid appearance (forming clusters, cords, alveolar groups and linear sequences) that can be confused microscopically with invasive lobular carcinoma).

Cytology, histopathology and immunohistochemistry are very helpful for accurate diagnosis in myofibroblastoma (8). In this study, we also demonstrated the cyto-histopathological findings of a breast myofibroblastoma with morphological findings. As in all cases in the literature, immunohistochemical findings of this tumor were positive for CD34 and vimentin (9). Desmin and SMA markers were also positive, as was the case in most cases. Pan-cytokeratin EMA, S-100 and CD117 markers, which were generally negative, were also negative in our case. CD10, which was positive in very few cases, was negative in this case (9). Due to the rarity of myofibroblastoma, preoperative diagnosis of cytology has still not been established. The FNA cytological features of the 22 cases in the literature are basically similar and consist of single and cluster benign spindle cells (9). Although most of the aspirates were hypercellular, aspiration of our case was hypocellular. There was no significant nuclear atypia in our case, there was mild to moderate pleomorphism and nuclear grooves and inclusions as seen in some cases $(9,10)$. As a result of FNA, we diagnosed "benign spindle cell neoplasm" as in most cases. The differential diagnosis of classical type myofibroblastoma involves spindle cell tumors and tumor-like lesions. They originate primarily from the breast parenchyma (9). Spindle and epithelial cells should be considered together in the evaluation of spindle cell lesions. Clinical and radiological features, as well as the presence and degree of atypia, growth pattern, mitotic activity and immunohistochemical examination should all be evaluated together (11). Spindle cell/mesenchymal lesions should not be diagnosed as malignant unless there are large number of mitotic figures and atypical and prominent pleomorphism (9). In the absence of these features, histopathological evaluation can eliminate the suspicions in cytology. In our case, benign spindle cells forming hyalinized collagen bands in the stroma were helpful in the diagnosis.

\section{Conclusion}

The first step in the approach to spindle cell lesions can be cytomorphology, however, immunohistochemical studies should not be ignored in the differential diagnosis of myofibrolastoma.

Informed Consent: Verbal and written informed consent was obtained from the patient who participated in this study.

Peer-review: Externally peer-reviewed.

Author Contributions: Concept - B.Y.B., A.T.E.; Design - B.Y.B.; Supervision - B.Y.B., A.T.E.; Resources - B.Y.B., A.T.E.; Materials - B.Y.B., A.T.E.; Data Collection and/or Processing - B.Y.B., A.T.E.; Analysis and/ or Interpretation - B.Y.B.; Literature Search - B.Y.B.; Writing Manuscript B.Y.B., A.T.E.; Critical Review - B.Y.B., A.T.E.

Conflict of Interest: There is no conflict of interest with any institution or company.

Financial Support: The authors declared that they did not receive financial support for this study.

\section{References}

1. Wargotz ES, Weiss SW, Norris HJ. Myofibroblastoma of the breast: sixteen cases of a distinctive benign mesenchymal tumor. Am J Surg Pathol 1987; 11: 493502.

2. Magro G. Mammary myofibroblastoma: a tumor with a wide spectrum. Arch Pathol Lab Med 2008; 132: 1813-20.

3. Álvarez-Rodriguez F, Gimeno-Aranguez M, López-Varela C, González-Peramato P, Tortoledo-Bruni A, Rodríguez-Costa J, et al. Fine-needle aspiration cytology of mammary myofibroblastoma: a report of six cases. Acta Cytol 2012; 56: 501-5.

4. Flucke U, van Krieken JH, Mentzel T. Cellular angiofibroma: analysis of 25 cases emphasizing its relationship to spindle cell lipoma and mammary-type myofibroblastoma. Mod Pathol 2011; 24: 82-9.

5. Wargotz ES, Deos PH, Norris HJ. Metaplastic carcinomas of the breast. II. Spindle cell carcinoma. Hum Pathol 1989; 20: 732-40.

6. Magro G, Flecher C, Eusebi V. Myofibroblastoma. In: Lakhani SR, Ellis IO, Schnitt SJ, Tan PH, van de Vijver NJ, eds. WHO classification of tumours of the breast. Lyon: IARC Press 2012; 130-1.

7. Schnitt SJ. Spinde cell lesions of the breast. In: Collins LC, ed. Current concepts in breast pathology. Philadelphia, PA: W.B. Saunders; 2009: 375-90.

8. Salemis NS, Nakos G, Tsiambas E, Tsantilas V, Seretis C. Rapidly growing myofibroblastoma of the breast diagnosed in a premenopausal woman: Management and review of the literature. Breast Dis 2012; 34: 29-34.

9. Fügen A, Elif S, Gülistan G, Meryem D, Günay G. Fine-needle aspiration cytology of a mammary myofibroblastoma: A case report on the role of immunohistochemistry and cell block preparations and a review of the literature. Diagn Cytopathol 2016; 44: 1064-9.

10. Yang CS, Chang MC, Jan YJ, Wang J. Fine needle aspiration of breast myofibroblastoma. Acta Cytol 2010; 54: 356-8.

11. Mac DeMay R. The art \& science of cytopathology. Superficial aspiration cytology. In: Breast. $2^{\text {nd }}$ edition, Chicago: ASCP Press; 2012. p. 1052-118. 